Review Article

\title{
Brachiaria spp. poisoning of ruminants in Brazil ${ }^{1}$
}

\author{
Beatriz Riet-Correa ${ }^{2}$, Marcio Botelho Castro ${ }^{3}$, Ricardo A.A. de Lemos ${ }^{4}$, \\ Gabriela Riet-Correa ${ }^{5}$, Vanessa Mustafa ${ }^{3}$ and Franklin Riet-Correa ${ }^{*}$
}

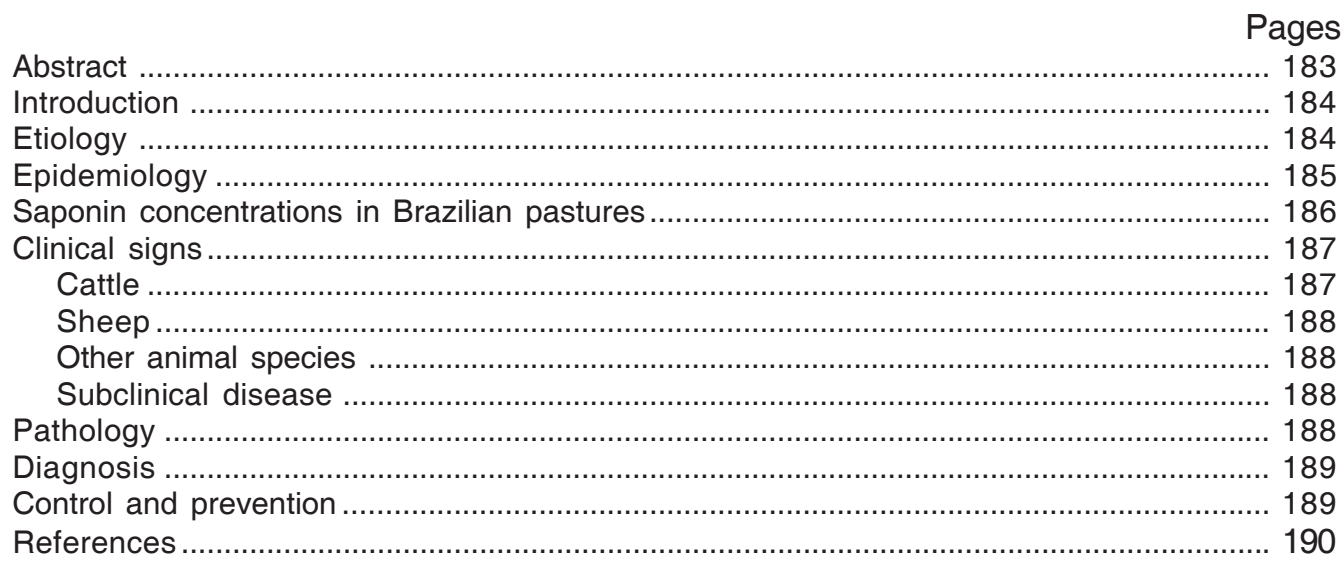

ABSTRACT.- Riet- Correa B., Castro M.B., Lemos R.A., Riet-Correa G., Mustafa V. \& RietCorrea F. 2011. Brachiaria spp. poisoning of ruminants in Brazil. Pesquisa Veterinária Brasileira 31(3):183-192. Hospital Veterinário, Centro de Saúde e Tecnologia Rural, Universidade Federal de Campina Grande, Campus de Patos, 58700-070 Patos, PB, Brazil. E-mail: franklin.riet@pq.cnpq.br

Brachiaria species are the most important grasses for cattle production in Brazil. However, a limiting factor for the use of Brachiaria spp. is their toxicity. Most outbreaks of hepatogenous photosensitization are caused by $B$. decumbens; however $B$. brizantha, $B$. humidicola and $B$. ruziziensis can also cause poisoning. The poisoning affects cattle, sheep, goats and buffalo. Sheep are more susceptible than other animal species and the young are more susceptible than adults. There are differences in susceptibility among animals of the same species and it has been suggested that this resistance is genetic. Also has been suggested that buffalo and probably some sheep are resilient, i.e. when poisoned these animals have histologic lesions and high GGT serum concentrations, but do not show clinical signs. In general, saponin concentrations are higher in growing plants, but outbreaks occur all over the year, probably due to unexplained rise in saponin concentration in the plant. A clinical syndrome of progressive weight loss and death, without photosensitization, has been reported in cattle poisoned by $B$. decumbens. Main preventive measures are based on the selection of resistant or resilient animals and on the development of Brachiaria species or varieties with low saponin concentration.

INDEX TERMS: Brachiaria spp., foamy macrophages, lithogenic saponin, photosensitization, progressive weight loss, resilience, resistance.

\footnotetext{
${ }^{1}$ Received on September 20, 2010.

Accepted for publication on November 10, 2010.

${ }^{2}$ Hospital Veterinário, Centro de Saúde e Tecnologia Rural (CSTR), Universidade Federal de Campina Grande (UFCG), 58700-000 Patos, PB, Brazil. *Corresponding author: franklin.riet@pq.cnpq.br

${ }^{3}$ Curso de Medicina Veterinária, Universidade de Brasília (UNB), Campus Darcy Ribeiro, Brasilia, DF 70910-970, Brazil.
}

\footnotetext{
${ }^{4}$ Departamento de Medicina Veterinária, Faculdade de Medicina Veterinária e Zootecnia, Universidade Federal de Mato Grosso do Sul (UFMS), Campus Universitário, Caixa Postal 549, Campo Grande, MS 79070-900, Brazil.

${ }^{5}$ Faculdade de Medicina Veterinária, Universidade Federal do Pará (UFPA), Rua Maximino Porpino da Silva 1000, Castanhal, PA 68743-080, Brazil
} 
RESUMO.- [Intoxicação por Brachiaria spp. em ruminantes no Brasil.] Brachiaria spp. são as forrageiras mais importantes para a pecuária brasileira. Entretanto, um fator limitante para sua utilização é a sua toxicidade. A maioria dos surtos de fotossensibilização hepatógena é causada por Brachiaria decumbens; porém, B. brizantha, B. humidicola e $B$. ruziziensis podem também causar intoxicação. A intoxicação afeta bovinos, ovinos, caprinos e bubalinos. Os ovinos são mais susceptíveis que as outras espécies, e os animais jovens são mais susceptíveis que os adultos. Existem diferenças na susceptibilidade entre animais da mesma espécie e tem sido sugerido que esta resistência é genética. Sugere-se, também, que búfalos e provavelmente alguns ovinos são resilientes (quando intoxicados apresentam lesões histológicas e aumento das concentrações séricas de GGT, mas não apresentam sinais clínicos). Em geral, a concentração de saponinas é maior nas plantas em crescimento, mas surtos ocorrem durante todo o ano, provavelmente por aumento da concentração de saponinas na planta por alguma causa ainda desconhecida. Uma síndrome clínica com progressiva perda de peso e morte, sem fotossensibilização, tem sido descrita em bovinos intoxicados por $B$. decumbens. As principais medidas preventivas são baseadas na seleção de animais resistentes ou resilientes e o desenvolvimento de espécies ou variedades de Brachiaria com menores concentrações de saponinas.

TERMOS DE INDEXAÇÃO: Brachiaria spp., macrófagos espumosos, saponinas litogênicas, fotosensibilização, perda progressiva de peso, resiliência, resistência.

\section{INTRODUCTION}

Brachiaria decumbens, originally from Africa, was first introduced into Brazil in 1962 by the Instituto de Pesquisas Experimentais Agropecuárias do Norte (IPEAN). Because $B$. decumbens $\mathrm{cv}$. Ipean is reproduced by stolons, it expanded slowly. In 1972, B. decumbens cv brasilisk was introduced from Australia. Because it reproduces by seed, this species spread rapidly throughout the Midwest, North and South of Brazil (Seiffert 1980). Currently there are several $B$. decumbens cultivars in Brazil. B. brizantha, which has gradually replaced $B$. decumbens, was introduced in the 1980s. The main reason for this replacement was $B$. brizantha resistance to spittlebugs (insects of the order Homoptera, family Cercopidae, genera Zulia, Mahanarva and Deois), which can cause severe damage to $B$. decumbens pastures (Embrapa 2005). B. decumbens has been associated with photosensitization outbreaks in ruminants since its introduction into Brazil (Camargo et al. 1976, Döbereiner et al. 1976, Nobre \& Andrade 1976, Nazário et al. 1977, Tokarnia et al. 2000). Outbreaks of photosensitization in $B$. decumbens cv Ipean pastures have not been reported (Seiffert 1980); however, this is difficult to prove because of the lack of knowledge about the origin of $B$. decumbens found on several farms where outbreaks have been observed.

Brachiaria brizantha cv. Marandú was introduced in 1983 by Embrapa (Brazilian Enterprise for Agicultural Research) and gradually replaced $B$. decumbens in large areas. From
1996 to 1997 , B. brizantha seeds accounted for about $50 \%$ of the forage seed market in Brazil. Currently, an estimated 60 million hectares are planted with $B$. brizantha in the country. Photosensitization outbreaks in ruminants have also occurred on pastures of this species (Lemos et al. 1996a, Albernaz et al. 2008, Mustaffa 2009, Silveira et al. 2009, Souza et al. 2010) or in mixed pastures of $B$. decumbens and B. brizantha (Souza et al. 2010).

$B$. humidicola is native to eastern and southern Africa, where it occurs in relatively moist areas. It has also played a relevant role in the Brazilian northern region (Amazon) since 1983 , where it has largely replaced $B$. decumbens due to its spittlebug tolerance (Seiffert 1980). Pastures with this species also increased in the Brazilian cerrado (a vast tropical savanna area in Brazil) (Serrão 1977). B. humidicola poisoning has been reported in sheep (Lau \& Singh 1985) and buffalo (Schenk \& Schenk 1983). Of the three Brachiaria species above mentioned, the latter is the only one used for horse feeding, though it can also cause photosensitization in these animals (Schenk et al. 1991, Barbosa et al. 2006). Other species of Brachiaria include B. purpurascens, B. dictyoneura, B. ruziziensis, B. radicans, B. extensa. B. plantaginea, B. dura and B. milliformis (Seiffert 1980), but only $B$. ruziziensis has been associated with photosensitization outbreaks (Nazário et al. 1985, Purchio et al. 1988).

There are about 60 million hectares of cultivated pastures in the Brazilian Cerrado. Of this total, 51 million hectares consist of Brachiaria spp; about 30 million hectares of $B$. brizantha, 15 million hectares of $B$. decumbens, and six million hectares of $B$. humidicola and other Brachiaria (Macedo 2005).

Due to its high dry matter production, easy cultivation, easy adaptation to different soils for year-round growth, and the low maintenance cost of the cultivated area, Brachiaria spp are the most important forage in Midwestern, Southeastern, and Northern Brazil (Seiffert 1980, Drudi et al. 1995). Despite their excellent forage quality, a limiting factor for the use of Brachiaria spp. is their toxicity, as these plants can cause hepatogenous photosensitization, leading to economic losses due to decreased productivity and animal death (Fagliari et al. 1993b, Fioravante 1999, Riet-Correa \& Medeiros 2000).

This paper aims to review aspects of the etiology, epidemiology, clinical signs, pathology, diagnosis, control, and prevention of Brachiaria spp. poisoning in ruminants in Brazil.

\section{ETIOLOGY}

Ever since the first outbreaks of Brachiaria poisoning several authors have blamed Pithomyces chartarum as the cause of the disease (Camargo et al. 1976, Döbereiner et al. 1976, Nazàrio et al 1977, Temperini \& Barros 1977, Fagliari et al. 1983, 1994, Lau \& Singh 1985, Lau 1990, Soares et al. 2000, Russomanno et al. 2003, Górniak 2008). However, since 1985 authors have suggested that Brachiaria toxicity is due to lithogenic steroidal saponins contained in this grass. Researchers from Australia, Malaysia and Indonesia have been unable to isolate $P$. chartarum from $B$. decumbens 
pastures causing photosensitization (Opasina 1985, ZamriSaad et al. 1987, Graydon et al. 1991, Salam-Abdullah et al. 1992). Brewer et al. (1989) examined the sporodesminproducing ability of $20 \mathrm{P}$. chartarum isolates from Colombia, 2 from Texas, 3 from Nova Scotia, and 32 from Brazil. None of these isolates, including those collected in Brazil, produced sporodesmin. Collin et al. (1996) examined 51 isolates from two different regions in Brazil collected from pastures causing photosensitization, and only one sample produced sporodesmin. Graydon et al. (1991) reported in ruminants poisoned by $B$. decumbens crystals in the bile ducts, similar to those observed in Tribulus terretris and Panicum spp. poisoning, which contain lithogenic saponins, suggesting that these compounds are also $B$. decumbens toxic compounds. In Brazil, several authors have reported the presence of crystals in the liver of sheep (Lemos et al. 1996b, Driemeier et al. 2002, Brum et al. 2007, Castro et al. 2009), goats (Lemos et al. 1998), and cattle (Lemos et al. 1996a, Driemeier et al. 1998, Souza et al. 2010) poisoned by Brachiaria spp. In addition, varying levels of lithogenic saponins were found in toxic Brachiaria pastures without $P$. chartarum or with low number of spores (Cruz et al. 2000, Brum et al. 2007, Castro et al. 2009, Mustafa 2009). Cruz et al. (2001) have induced cholangiopathy in the presence of crystals in lambs by administering $B$. decumbens extracts. These studies excluded the hypothesis of the fungus $P$. chartarum being the cause of photosensitization in Brachiaria pastures, and demonstrated that this poisoning is caused by lithogenic saponins contained in the grass.

The lithogenic steroidal saponins (dicotomin, protodioscin and saponin B) contained in Brachiaria spp. and Panicum spp. induce the formation of crystals in the biliary system. Saponin hydrolysis results in diosgenin and yamogenin sapogenins which, after being metabolized in the digestive tract, produce espismilagenin and episarsasapogenin sapogenins, which in turn conjugate with glucuronic acid forming glucuronides; these bind with calcium ions to form insoluble salts that are deposited in the form of crystals (Meagher et al. 1996, Lee et al. 2009). Protodioscin has been the main saponin found in Brachiaria spp. (Brum et al. 2007, 2009, Castro et al. 2009, Santos Jr 2008, Mustafa 2009).

\section{EPIDEMIOLOGY}

In Brazil, Brachiaria poisoning affects cattle (Fagliari et al. 1993a, Lemos et al. 1996a, 1997), sheep (Lau \& Singh 1985, Lemos et al. 1996b, Driemeier et al. 2002, Brum et al. 2007, Mustafa 2009), goats (Lemos et al. 1998, Silveira et al. 2009), and buffalo (Schenk \& Schenk 1983, Rozza et al. 2004) throughout the country. Poisoning can occur at any time of the year and at any stage of the plant, both in sheep (Mustafa 2009) and cattle (Souza et al. 2010). Some authors mention a higher frequency of the poisoning during pasture sprouting (Riet-Correa \& Méndez 2007). One outbreak in calves occurred on a mature $B$. decumbens pasture left ungrazed for over 30 days (Lemos et al. 1997), but it is not clear if the occurrence of such outbreak was due to the higher toxicity of the pasture or to the high sus- ceptibility of the recently weaned calves coming from an area without Brachiaria in the Pantanal of Mato Grosso do Sul. When a pasture of $B$. decumbens was examined at 14,45 and 90 days after being cut, saponin concentrations and toxicity to sheep showed a gradual decrease from the $15^{\text {th }}$ to the $90^{\text {th }}$ day of growth on (Castro et al. 2009).

Sheep are more susceptible to poisoning than cattle (RietCorrea \& Méndez 2007, Lemos et al. 2009) and the absence of the disease in goats grazing together with sheep with photosensitization suggests that goats are also more resistant than sheep (Abas-Mazni et al. 1985, Opasina 1985). Young animals are more susceptible than adults. In central Brazil, 10 out of 11 outbreaks in sheep affected animals under one year of age (Mustafa 2009). In cattle, young animals up two years of age are more frequently affected (Fagliari et al. 1993a, Souza et al. 2010). The poisoning occurs mainly in calves near weaning or just weaned. However, adult cattle may also be affected (Noble \& Andrade 1976, Tokarnia et al. 2000, Riet-Correa \& Méndez 2007, Lemos et al. 2009). Poisoning can also occur in lactating animals (Lemos et al. 1996a), sometimes up to 30 days old (Fagliari et al. 1983). It has been demonstrated that there are differences in susceptibility between animals of the same species (Castro et al. 2009). High susceptibility to poisoning has been observed in sheep raised in Brachiaria-free areas that are later transported to Brachiaria pastures (Castro et al. 2009) suggesting that animals raised on Brachiaria pastures are less susceptible to poisoning than sheep raised on other pastures (Castro et al. 2007, 2009). Because sheep that survive poisoning can be affected twice or more times, while other sheep from the same flock may never be affected, it has been suggested that resistance is genetic. Also, it was not possible to adapt susceptible sheep to the ingestion of toxic B. decumbens (Aniz 2008). Nevertheless, acquired resistance in animals raised on Brachiaria pastures cannot be discarded. In cattle, Brachiaria poisoning was clearly more frequent from 1960 to 1980 , i.e. in the early periods after the introduction of this forage. Subsequently, outbreaks were less frequent, apparently due to the death of susceptible animals or to the development of poisoning resistance. Another possibility is that the decrease in the number of outbreaks is a result of the replacement of $B$. decumbens, which is more toxic, by the less toxic $B$. brizantha and $B$. humidicola. It has also been suggested that buffalo and probably some sheep are resilient, that is they can be poisoned without showing any clinical signs. In buffalo showing no clinical signs slaughtered in the State of Pará, $100 \%$ of the animals from Brachiaria pastures showed severe lesions in the liver (swelling, vacuolation and individual necrosis of hepatocytes, presence of numerous foamy macrophages, and subcapsular fibrosis) suggesting that this species is resilient to Brachiaria poisoning (Riet-Correa et al. 2010). Castro et al. (2009) also found that sheep that did not show clinical signs after their introduction into $B$. decumbens pastures showed high AST and GGT levels, similar to sheep with clinical signs, suggesting that the former were resilient to Brachiaria poisoning. 
Most outbreaks of poisoning are caused by $B$. decumbens (Camargo et al. 1976, Döbereiner et al. 1976, Noble \& Andrade 1976, Fagliari et al. 1983, 1993b, Lemos et al. 1996b, 1997, 1998, Brum et al. 2007, Mustafa 2009, Souza et al. 2010). Outbreaks by B. brizantha (Lemos et al 1996a, Mustafa 2009); B. humidicola (Schenk \& Schenk 1983, Lau 1990) and B. ruziziensis (Nazario et al. 1985, Purchio et al. 1988, Tokarnia et al. 2000) are less frequent. In a study of 11 outbreaks in sheep in Central Brazil, $B$. decumbens was involved in 8 outbreaks; 2 were caused by $B$. brizantha and 1 occurred on a $B$. decumbens and $B$. humidicola mixed pasture (Mustafa 2009). In Mato Grosso do Sul, out of 29 outbreaks of Brachiaria poisoning in cattle, 16 were caused by $B$. decumbens, 2 occurred in $B$. decumbens and $B$. brizantha mixed pastures, and 1 on a $B$. brizantha pasture; in 10 outbreaks, the Brachiaria species present in the pasture was not reported (Souza et al. 2010). In the same State, a total of 21 outbreaks in sheep were caused by B. decumbens (Lemos et al. 2009). Two outbreaks in goats occurred on $B$. decumbens pastures (Lemos et al. 1998); however, occasional cases have been reported on B. brizantha pastures (Silveira et al. 2009). Over 100 outbreaks reported by the School of Veterinary and Animal Science at São Paulo State University (Unesp) in cattle from Mato Grosso do Sul, Goiás and Minas Gerais States between 1979 and 2009 were caused by B. decumbens $\mathrm{cv}$ brasilisk. During the same period of time, about 20 isolated cases of $B$. brizantha poisoning were observed (Jurandir Fagliari 2010, personal communication). B. decumbens has been almost entirely replaced by $B$. brizantha in Goiás and in the last 20 years there has been a gradual reduction of outbreaks in cattle. Currently only occasional cases on $B$. brizantha pastures are being reported, most often in pastures with new growth after the onset of the rainy season or after pasture burning (Maria Clorinda Fioravanti 2010, personal communication). Considering that in the Brazilian Cerrado there are nearly 30 million $B$. brizantha hectares, 15 million $B$. decumbens hectares and 6 million $B$. humidicola and other Brachiaria spp. hectares (Macedo 2005), it is clear that the higher frequency of outbreaks on $B$. decumbens pastures is due to their greater toxicity.

In a review on the frequency of 18 outbreaks of Brachiaria poisoning in sheep, the morbidity rate ranged from $15.4 \%$ to $57.1 \%$, the mortality rate was $15-42.8 \%$ and case fatality rate 29.4-86.5\% (Mustafa 2009). In 29 cattle outbreaks in Mato Grosso do Sul, the morbidity rate ranged from $0.2 \%$ to $50 \%$, and the fatality rate from $44.4 \%$ to $100 \%$ (Souza et al. 2010). In the same State, in 21 outbreaks in sheep, the morbidity rate ranged from $4.6 \%$ to $60 \%$, and the fatality rate from 50 to $100 \%$ (Lemos et al. 2009). In two goat outbreaks, the morbidity rate was between $15 \%$ and $11 \%$, and the fatality rate was $100 \%$ (Lemos et al 1998). In five outbreaks of progressive weight loss associated with grazing $B$. decumbens, the morbidity ranged from $0.02 \%$ to $18 \%$ and the fatality rate from $26.67 \%$ to $100 \%$ (Souza et al. 2010).

\section{SAPONIN CONCENTRATIONS ON BRAZILIAN PASTURES}

Brum et al. (2007) found a concentration of $2.36 \%$ protodioscin in a growing Brachiaria decumbens pasture that caused sheep poisoning. In this study, a neighboring $B$. decumbens pasture grazed by cattle without any sign of photosensitization contained $1.63 \%$ protodioscin. In another study in experimental $B$. decumbens and $B$. brizantha plots at different stages of growth, protodioscin concentrations in B. brizantha were $0.53 \%, 1.03 \%, 0.83 \%$, and $2.09 \%$ during growth, flowering, seeding, and after seeding, respectively, and B. decumbens concentrations were $0.92 \%, 0.95 \%$, $0.82 \%$, and $1.94 \%$ for the same phases (Brum et al. 2009). In a trial to determine the susceptibility of two groups of sheep, one naïve and another raised in areas with Brachiaria spp, the protodioscin concentrations in $B$. decumbens was $1.06 \%$ at the beginning of the experiment on June 10 , when the grass was sprouting, and this percentage gradually decreased to $0.56 \%$ at the end of the experiment, when the pasture was dry, on August 1. In-between values were $0.95 \%$ on June $17,0.88 \%$ on June $24,1.11 \%$ on July 3 , $0.61 \%$ on July 10 , and $0.69 \%$ on July 18 . In this experiment, 9 out of 10 naïve sheep were poisoned. In contrast in sheep raised on Brachiaria spp. only one out of 10 were affected (Castro et al. 2007).

In an experiment to determine $B$. decumbens toxicity in its various stages of growth, lambs were placed on pasture of 15,45 and 90 days of growth (Santos Jr 2008, Castro et al. 2009). Protodioscin values are presented in Table 1. Sprouting pasture was more toxic than the others in this experiment (Santos Jr. 2008).

In a trial to determine weight gains in lambs grazing different grass species, the average protodioscin levels were $0.86 \%, 0.54 \%, 0 \%$ and $0.12 \%$ for B. decumbens, B. brizantha, Panicum maximum, and Andropogon gayanus, respectively. In lambs raised on Brachiaria spp. pastures weight gains were similar in the different pastures, except for those on $A$. gayanus, which did not gain as much weight (Castro et al. 2009). However, naïve sheep, raised on pastures other than Brachiaria spp., were poisoned when introduced into $B$. decumbens pastures. Protodioscin concentrations diminished during pasture maturation. The average levels for $B$. decumbens were $1.28 \%$ on April 3, $1.23 \%$ on April $29,1.44 \%$ on

\section{Table 1. Protodioscin concentrations on Brachiaria decumbens pasture paddocks at different stages of growth}

\begin{tabular}{cccc}
\hline Date & \multicolumn{3}{c}{$\begin{array}{c}\text { Pasture growth at the beginning } \\
\text { of the experiment on March } 18,2007\end{array}$} \\
\cline { 2 - 4 } & 15 days & 45 days & 90 days \\
\hline March 18 & $1.85 \%$ & $1.97 \%$ & $1.5 \%$ \\
April 5 & $1.90 \%$ & $2.21 \%$ & $1.91 \%$ \\
April 19 & $2.00 \%$ & $1.27 \%$ & $0.94 \%$ \\
May 3 & $2.05 \%$ & $1.53 \%$ & $1.19 \%$ \\
May 17 & $2.37 \%$ & $1.20 \%$ & $0.77 \%$ \\
Mean \pm SD & $2.03 \pm 0.20^{\mathrm{a}}$ & $1.63 \pm 0.44^{\mathrm{a}}$ & $1.26 \pm 0.45^{\mathrm{b}}$ \\
\hline
\end{tabular}

Different letters on the same line mean significant differences $(P<0.05)$. 
May $12,1.12 \%$ on May 26 , and $0.4 \%$ on June 23 . For $B$. brizantha, the levels were $1.21 \%$ on April $3,0.65 \%$ on April 29, 0.78 on May 12, $0.7 \%$ on May 26, and $0.36 \%$ June 23.

In an experiment on a $B$. brizantha pasture, protodioscin concentrations were significantly higher in young leaves than in mature or senescent ones (Barbosa et al. 2009).

In two $B$. decumbens samples, saponin concentrations were $1.55 \%$ and $1.15 \%$, and a B. brizantha pasture contained $0.628 \%$ saponin. The three samples came from Brachiaria pastures causing photosensitization in sheep (Lee et al. 2009).

In the state of Goiás, protodioscin values were determined periodically during a 30 month period on $B$. decumbens and $B$. brizantha pastures, and ranged from $0.03 \%$ to $1.09 \%$. The animals showed no clinical signs of poisoning on these pastures, but the high AST and GGT serum concentrations found were suggestive of subclinical poisoning (Moreira et al. 2009a).

In pasture samples collected during five photosensitization outbreaks in sheep, protodioscin concentrations ranged from $0.3 \%$ to $2.56 \%$. Concentrations of three samples collected during the dry period were $0.3 \%, 1.6 \%$ and $0.8 \%$, and samples collected in the rainy season contained $2.56 \%$ and $1.29 \%$ protodioscin (Mustafa 2009).

Very high concentrations of saponins, ranging from $2.15 \%$ to $3.03 \%$, were found in 11 samples of a pasture of $B$. decumbens, extremely toxic for sheep. The samples were collected from January 15 to April 30, during the rainy season (Saturnino et al. 2010, Haraguchi \& Barbosa 2008, unpublished data).

The results presented above, though insufficient, suggest that sheep poisoning occurs due to high saponin concentrations on the pasture, usually over $1 \%$; however, a toxicity threshold is yet to be established. Besides the lack of data, several factors contribute to this uncertainty, including the higher susceptibility of young animals and the greater resistance of animals raised on Brachiaria spp. pastures. Furthermore, saponin concentrations in the pasture samples collected during the observation of clinical signs probably did not represent the concentrations at the time of poisoning. For cattle and goats, which are more resistant than sheep, there are no data to estimate a toxic threshold.

In conclusion, most of the data show that sprouting pastures have higher saponin concentrations than mature ones (Santos Jr 2008, Castro et al. 2009) and young leaves contain more saponin than mature or senescent leaves (Barbosa et al. 2009). However, in one experiment, higher saponin concentrations were found on mature pasture (Brum et al. 2009), and poisoning outbreaks occurred at any time of the year (Mustafa 2009, Souza et al. 2010), as well as on mature pastures that had been left ungrazed for some period (Lemos et al. 1997). These observations suggest that the outbreaks can occur at any time of the year (Mustafa 2009, Lemos et al. 2009, Souza et al. 2010) due to a sudden increase in saponin cocentration on the pastures, may be because of climatic factors. New studies should be carried out with systematic and periodic saponin determinations in
Brachiaria spp. for longer periods in order to determine the possible significance of these variations.

In two photosensitization outbreaks in horses grazing $B$. humidicola, protodioscin concentration was $0.01 \%$ on one pasture whereas the other pasture showed no measurable protodioscin, dichotomin, or saponin B (Lee et al. 2009). These results suggest that photosensitization in horses could be caused by other $B$. humidicola compounds. Another possibility is that the disease was caused by a rise in saponin content of the pastures for a short period of time, having later returned to lower concentrations at the time of sample collection.

\section{CLINICAL SIGNS}

\section{Cattle}

In cattle two different clinical conditions have been reported: hepatogenous photosensitization and progressive weight loss (Lemos et al. 1997, Riet Correa et al. 2002, Souza et al.2010). Moreover, there is also a subclinical disease characterized by lower productivity (Fagliari et al. 1993c, Fioravante 1999, Moreira et al. 2009a).

Hepatogenous photosensitization is characterized initially by anorexia, depression, decrease or cessation of ruminal movements, dry feces, search for shade, and edema of the brisket and ears or other body parts. Later dermatitis showing swollen, thickened skin with yellow exudate can be observed, initially on the muzzle, ears, flanks, perineum, udder and in areas of white skin. After some days there is jaundice, ear and eye crusts, and ulcerations on the ventral tongue. Drooling, dark urine and eye discharge can also be observed. Some animals show restlessness or lie down for long periods, groaning or making other signs of pain. After 45 days, the skin becomes cracked and thickened with crust formation. A common finding is thickening and scar retraction of the ears, which are deformed and crooked.

The clinical manifestation period is variable; whereas some animals die within 5-7 days, others can have a clinical course of up to 60 days (Riet-Correa \& Méndez, 2007, Souza et al. 2010). In severe cases, the animals die within two or three days, without showing the characteristic signs of photosensitization or jaundice (Souza et al. 2010). Nervous signs have been observed in two cases in Mato Grosso do Sul (Souza et al. 2010).

Fagliari et al. (1993b) classify cattle poisoning into subclinical, acute, chronic moderate, and chronic severe. The subclinical form is characterized by weight loss and lack of signs. In moderate chronic poisoning, there are moderate skin lesions without jaundice, which tend to regress within 8-30 days after the first signs have appeared. Severe chronic poisoning is characterized by severe lesions on the face and nose, and jaundice; weight loss becomes more evident, and it takes over 30 days for spontaneous healing to occur; many animals may die in the meantime. The acute condition is characterized by superficial skin lesions without jaundice and death may occur within two to five days after the onset of the clinical disease.

A clinical condition characterized by progressive weight loss, anorexia, apathy, emaciation and death after a few 
months without photosensitization has been reported in cattle over two years of age, grazing Brachiaria decumbens (RietCorrea et al. 2002). Five outbreaks of this syndrome were diagnosed in Mato Grosso do Sul from 1996 to 2008 in cattle of different ages (Lemos et al. 2009, Souza et al. 2010).

\section{Sheep}

In sheep, mainly in those which have been transferred from areas without Brachiaria spp. to areas with Brachiaria spp., there is an acute condition characterized by apathy, anorexia, photophobia, edema of the ear and face, conjunctival hyperemia, and ocular bilateral discharge. These animals do not develop jaundice or dermatitis and the clinical course lasts from 24 to 96 hours. The first signs occur 7-10 days or up to 50 days after the introduction of the sheep on the pasture (Castro et al. 2007, Santos Jr 2008, Mustafa 2009). However, the most frequent clinical presentation is subacute to chronic with a clinical manifestation period of 15-45 days. In this case the animal may show anorexia, depression, weight loss, swelling of the face and ears, conjunctivitis, ocular and nasal discharge, blindness, photophobia with continuous head movements, jaundice and dermatitis of the face and ears. In white-skinned hair sheep, dermatitis may occur in other white skin areas. In black animals of the Santa Ines breed, the only sign of photosensitization is periocular edema with runny eyes, epiphora and conjunctivitis. In wool sheep, dermatitis is restricted to the face and ears. In cases of longer evolution, the ears can be thickened and contorted with turned-up edges due to scar retraction. These subacute and chronic conditions can affect naïve sheep, as well as sheep raised on Brachiaria pastures (Castro et al. 2007, Santos Jr 2008, Mustafa 2009, Saturnino et al. 2010).

\section{Other animal species}

Goats show apathy, anorexia, dehydration, erythema, edema and dermatitis of the periocular skin, and skin of the muzzle, ears and vulva. Eye and nose discharge, runny nose and eyes, and jaundice are also observed (Lemos et al. 1998, Silveira et al. 2009). In a buffalo that showed photosensitization signs after staying for at least three weeks on a $B$. decumbens pasture, prostration, anorexia, weight loss and extensive areas of skin peeling were observed. The animal was euthanized after a clinical course of three weeks (Rozza et al. 2004). The same clinical signs and jaundice were observed by Tokarnia \& Langenegger (1983) in buffalo maintained on B. humidicola.

\section{Subclinical disease}

Fagliari et al. (1993c), Fioravante (1999) and Moreira et al. (2009ab) reported a subclinical form of the disease in cattle without clinical signs, but with lower weight gain, as evidenced by a negative correlation between the number of foamy macrophages in the liver and body weight at slaughter (Fioravante 1999). For this reason, some farmers and practitioners do not recommend the introduction of recently weaned animals into Brachiaria pastures. Castro et al. (2009), however, found no significant differences in weight gains when young sheep raised on Brachiaria pastures were introduced into $B$. brizantha, $B$. decumbens or Panicum maximum pastures; nevertheless, a flock introduced into a Andropogon gayanus pasture showed lower weight gain than the others. No significant differences were observed between slaughtered buffalo with liver lesions raised on Brachiaria pastures and those raised on other pastures without liver lesions.

\section{Clinical pathology}

Increased serum activity of gamma glutamyl transferase (GGT), aspartate aminotransferase (AST) and increased serum concentrations of total, direct and indirect bilirubin have been detected in natural and experimental Brachiaria poisoning in cattle and sheep (Fagliari et al. 1994, Fioravanti 1999, Lemos \& Purisco 2002, Mendonça et al. 2008, Castro et al. 2007, Santos Jr et al. 2008, Saturnino et al. 2010). Increased serum GGT levels are the best predictors of the onset of the poisoning, tending to remain high for a longer period (Fagliari et al. 1994, Castro et al 2007, Santos Jr 2008, Saturnino et al. 2010). However, increased AST and GGT levels did not correlate with the severity of poisoning (Castro et al. 2007, 2009, Santos Jr 2008).

\section{PATHOLOGY}

The main macroscopic lesions, in addition to dermatitis, are jaundice, an enlarged yellowish or brownish liver, a distended gallbladder with edematous wall, subcutaneous yellowish edema, ascites, hydropericardium, hydrothorax, gelatinous atrophy of visceral fat, and wasting. The kidney may be darkened, and the urine dark brown. In more acute cases without dermatitis, the main lesions are subcutaneous edema, hepatomegaly, jaundice and gallbladder distention. In chronic cases, the liver may show an increased lobular pattern, increased consistency, or an irregular thickened and whitish surface (Lemos et al. 1996, Tokarnia et al. 2000, Riet-Correa \& Méndez 2007, Mendonça et al. 2008, Castro et al. 2009).

In cattle without clinical signs at slaughterhouses, the liver may appear yellowish, which becomes more evident after fixation. The cut surface of the mesenteric and hepatic lymph nodes show whitish grooves, extending from the cortex to the medullar, and small white nodules in the medullar. These lesions are sometimes associated with hemorrhages (Driemeier et al. 1998). Similar lesions of the liver and lymph nodes are found in cattle with progressive weight loss syndrome on B. decumbens pastures (Riet-Correa et al. 2002, Souza et al. 2010). A yellowish liver with a diffuse increased lobular pattern, increased consistency, and thickening of the capsule can be also observed in slaughterhouses in sheep raised on Brachiaria pastures (Boabaid et al. 2009).

Upon histologic examination of animals with clinical signs of Brachiaria poisoning, the liver shows vacuolation, swelling or necrosis of individual hepatocytes, bilestasis, lymphoplasmocytic cholangitis and pericolangitis and, in chronic cases, a varying degree of periportal fibrosis. The most characteristic lesions of Brachiaria spp. poisoning are the 
presence of birefringent crystals or negative images of these crystals in the bile ducts, macrophages and hepatocytes (Lemos et al. 1996b, 1997, 1998, Driemeier et al. 2002, Silveira et al. 2009, Santos Jr 2008), and the occurrence of macrophages with foamy cytoplasm, sometimes containing crystals (Lemos et al. 1997, Driemeier et al. 1998, 1999, 2002, Gomar et al. 2005, Santos Jr 2008, Moreira et al. 2009b). These macrophages, which can measure from 14 to $70 \mu \mathrm{m}$, appear either alone or in groups of 3 to 50 (Souza et al. 2010). Sometimes, more than 200 cells with fine cytoplasm vacuolation and central or peripheric nuclei can be found (RietCorrea et al. 2010). Giant cells with many nuclei in the center or on the periphery can also be observed. Groups of foamy macrophages occur mainly around the central vein, but they can be distributed throughout the parenchyma. On occasion, large areas of the parenchyma can be replaced by large groups of foamy macrophages (Fioravante 1999, Riet-Correa et al. 2010). Large numbers of single foamy macrophages, sometimes containing crystals, have been found in the sinuisoids in acute cases in sheep (Driemeier et al. 2002, Castro et al. 2007, 2009, Santos Jr 2008, Mustafa 2009) and less frequently in cattle (Souza et al. 2010). Negative images of crystals, occasionally associated with multinucleated giant cells (Brum et al. 2007), and dilatation of convoluted tubules and necrosis of epithelial cells (Mendonça et al. 2008) have been reported in the kidneys.

Foamy macrophages, most of which in groups and multinucleate, have been observed in the liver and lymph nodes of slaughtered animals without clinical signs raised on Brachiaria pastures. Other lesions of the liver are swelling and vacuolation of hepatocytes, periportal lymphoplasmocytic infiltration or fibrosis, and proliferation of bile duct epithelial cells (Fioravante 1999, Moreira et al. 2009b). Similar lesions may occur in cattle grazing on Andropogon gayanus pasture, which can also contain saponins (Moreira et al. 2009a,b). Tokarnia \& Langenegger (1983) observed a large number of foamy macrophages in the liver of a buffalo with photosensitization from a herd kept on a $B$. humidicola pasture. Livers of healthy buffalo raised on Brachiaria spp. pastures showed a marked infiltration by foamy macrophages, hepatocyte vacuolation, and other lesions, while buffalo from Marajó Island raised on native pastures without Brachiaria showed no lesions (Riet-Correa et al. 2010). Foamy macrophages in the liver of cattle were first observed in 1976 after the introduction of $B$. decumbens in Brazil from Australia (Driemeier et al. 1989).

Under electron microscopy, cleft-shaped structures, which represent the negative image of crystals, can be observed in hepatocyte and macrophage cytoplasm. These structures are covered with membranes, resembling phagolysosomes (Driemeier et al. 1998). Hyperplasia of the smooth endoplasmic reticulum has been observed in sheep (Driemeier et al. 2002, Santos Jr 2008).

\section{DIAGNOSIS}

Presumptive diagnosis is suggested mainly by epidemiological data, clinical signs and pathology. Some important epidemiological information includes: (1) grazing on Brachiaria spp. pastures, (2) young animals being more affected than adults, and (3) high frequency after the introduction into Brachiaria pastures of animals raised on pastures without these grasses. Clinical signs (photosensitization) and gross pathology are not very different than those observed in other plant poisonings that cause hepatogenous photosensitization. Histologically, the main lesion is the presence of crystals in the bile ducts or in macrophages or hepatocytes. The observation of foamy macrophages, which is characteristic of Brachiaria poisoning, should be interpreted with caution as these cells can also be observed in animals without clinical signs raised on Brachiaria pastures. The determination of lithogenic saponin concentrations in pastures may be useful. However, this technique is not commercially available in Brazil, and a toxicity threshold is yet to be established. Differential diagnosis should include Enterolobium spp. and Stryphnodendron spp. poisoning, which occurs when the fruits fall from these trees. In cattle poisoning by these plants, photosensitization is usually accompanied by digestive signs and/or abortions. Poisoning by Lantana spp. is less common and occurs when naïve animals are put into areas that have been invaded by this plant or in low forage availability conditions. Myoporum laetum poisoning has been diagnosed only in the state of Rio Grande do Sul and occurs under very specific conditions, when such trees or their branches are cut or blown down. The differential diagnosis with Panicum spp. poisoning, which also contains lithogenic saponins, can only be established by the presence of this grass on the pasture.

Other skin conditions can be confused with photosensitization. In Mato Grosso do Sul, generalized skin lesions of dermathophilosis in Nelore calves are commonly observed on $B$. brizantha pastures and may be misdiagnosed as Brachiaria poisoning. The main differentiation with photosensitization caused by Brachiaria spp. is that scar retraction of the ears is not observed in dermatophilosis (Lemos \& Leal 2008). In sheep, acute cases of Brachiaria poisoning, without dermatitis or jaundice, should be differentiated from other acute diseases, including acute hemonchosis, which shows severe anemia.

\section{CONTROL AND PREVENTION}

Animals should be removed from toxic pastures to other pastures (Panicum maximum, Cynodon spp., Setaria spp., Digitaria spp.). However, Brachiaria spp. are the only pastures available on many farms. Such being the case, the herd has to be removed to another Brachiaria pasture, as some pastures are likely to be toxic, while others can be safe, on the same farm. The only treatment is symptomatic; but it is very important to keep the animals in the shade, with food and water provision.

There are no preventive measures to avoid the poisoning of livestock to be introduced into Brachiaria spp. pastures, especially when they come from areas without Brachiaria. However, animals should be gradually introduced 
for longer periods of time. This technique probably will not avoid poisoning, but clinical signs will be probably less severe, and the withdrawal of the animals from the toxic pasture after the observation of the first signs will be more efficient to avoid new cases.

In the long run, two possibilities should be considered for the prophylaxis of the poisoning: (1) the use of resistant animals, and (2) the selection of Brachiaria species or varieties with lower lithogenic saponin concentrations, therefore less toxic or non-toxic. Studies are being conducted to determine whether resistance to Brachiaria poisoning is either genetic or acquired. With this knowledge, selection programs for resistant animals can be developed, in case the resistance is hereditary; or methods to adapt animals to Brachiaria spp. consumption, in case it is acquired. No doubt, an alternative is the development of non-toxic Brachiaria spp. varieties. The likelihood of using this method in the future originates in the higher B. decumbens toxicity in relation to other Brachiaria spp. The use of the saponin concentration as a parameter in selection programs for Brachiaria varieties and/or species to be introduced into the market could significantly reduce the toxicity of Brachiaria spp. in Brazil.

Acknowledgements.- This study has been financially supported by the Brazilian National Research Council (CNPq), grant number 573534/ 2008-0.

\section{REFERENCES}

Abas-Mazni O., Sharif H. \& Khusahry M. 1985. Photosensitization in goats grazed on Brachiaria decumbens. Mardi Research Bulletin, Selangor, West Malaysia, 13(2):203-206.

Albernaz T.T., Silveira J.A.S., Reis A.B., Oliveira C.H.S., Oliveira C.M.C., Duarte M.D., Cerqueira V.D., Riet-Correa G. \& Barbosa Neto J.D. 2008. Fotossensibilização em ovinos associada à ingestão de Brachiaria brizantha no Pará. Encontro Nacional de Diagnóstico Veterinário, Campo Grande, MS, p.73-74. (Abstract)

Aniz A.C.M. 2008. Efeito da adaptação ao consumo de Brachiaria decumbens e a existência de resistência ou susceptibilidade individual em ovinos à intoxicação. Graduate Monography, Universidade Federal de Mato Grosso do Sul, Campo Grande, MS. 31p.

Barbosa J.D., Oliveira C.M.C., Tokarnia C.H. \& Peixoto P.V. 2006. Fotossensibilização hepatógena em eqüinos pela ingestão de Brachiaria humidicola (Graminae) no Estado do Pará. Pesq. Vet. Bras. 26:147-153.

Barbosa M.F., Brum K,B., Fernandes C.E., Martins C.F., Monteiro L.C. Vandeufrazio S.C., Rezende K.G., Riet-Correa F., Haraguchi M., Junior H.L.W. \& Lemos R.A.A. 2009. Variations of saponin level $x$ maturation in Brachiaria brizantha leaves. $8^{\text {th }}$ International Symposium on Poisonous Plants, João Pessoa, Paraíba, Brazil, p.13. (Abstract)

Boabaid F.M., Antoniassi N.A.B., Pescador C.A., Souza M.A., Gasparetto N.D., Cruz C.E.F., Bezerra P.S., Driemeier D. \& Colodel E.M. 2009. Lectin hischemistry on sections of liver and hepatic lymph nodes from sheep grazing on Brachiaria spp. $8^{\text {th }}$ International Symposium on Poisonous Plants, João Pessoa, Paraíba, Brazil, p.93. (Abstract)

Brewer D., Russel D.W., Amaral R.A.M. \& Aycardi E.R. 1989. An examination of North and South American isolates of Pithomyces chartarum for production sporidesmin and sporidesmolides. Proc. N. Z. Inst. Sci. 38:73-81.

Brum K.B., Haraguchi M., Lemos R.A.A., Riet-Correa F. \& Fioravante
M.C. 2007. Crystal associated cholangiopathy in sheep grazing Brachiaria decumbens containing the saponin protodioscin. Pesq. Vet. Bras. 27:39-42.

Brum K.B., Haraguchi M., Garutti M.B., Nóbrega F.N., Rosa B. \& Fioravanti M.C.S. 2009. Steroidal saponin concentrations in Brachiaria decumbens and $B$. brizantha at different developmental stages. Ciência Rural 39(1):279-281.

Camargo W.V.A., Nazário W., Fernandes N.S. \& Amaral R.E.M. 1976. Fotossensibilização em bovinos de corte: provável participação do fungo Pithomyces chartarum na etiologia do processo. Biológico, São Paulo, 42(5):249-261.

Castro M.B., Moscardini A.R.C., Reckziegel G.C., Novaes E.P.F., Mustafa V.S., Paludo G.R., Borges J.R.J. \& Riet-Correa F. 2007. Susceptibilidade de ovinos à intoxicação por Brachiaria decumbens. V Congresso Latinoamericano de Especialistas em Pequeños Ruminantes y Camélidos Sudamericanos, Buenos Aires, Argentina, p.57-59. (Abstract)

Castro M.B., Santos Jr H.L., Mustafa V.S., Gracindo C.V., Moscardini A.C.R., Louvandini H., Paludo G.R., Borges J.R.J., Haraguchi M., Ferreira M.B. \& Riet-Correa F. 2009. Brachiaria spp poisoning in sheep in Brazil: Experimental and epidemiological findings. $8^{\text {th }}$ International Symposium on Poisonous Plants. João Pessoa, Paraíba, Brazil. p.12. (Abstract)

Collin R.G., Odriozola E. \& Towers N.R. 1996. Sporidesmin production by Pithomyces chartarum isolates from Australia, Brazil, New Zealand and Uruguay. Mycol. Res. 106:163-166.

Cruz C., Driemeier D., Pires V.S., Colodel E.M., Taketa A.T.C. \& Schenkel E.P. 2000. Isolation of steroidal sapogenins implicated in experimentally induced cholangiopathy of sheep grazing Brachiaria decumbens in Brazil. Vet. Human Toxicol. 42:142-145.

Cruz C., Driemeier D., Pires V.S. \& Schenkel E.P. 2001. Experimentally induced cholangiopathy by dosing sheep with fractionated extracts from Brachiaria decumbens. J. Vet. Diag. Invest. 13:170172.

Döbereiner J., Tokarnia C.H., Monteiro M.C., Cruz L.C.H., Carvalho E.C. \& Primo A.T. 1976. Intoxicação de bovinos e ovinos em pastos de Brachiaria decumbens contaminados por Pithomyces chartarum. Pesq. Agropec. Bras., Sér. Vet. 11(1):87-94.

Driemeier D., Barros S.S., Peixoto P.V., Tokarnia C.H., Döbereiner J. \& Brito M.F. 1998. Estudo histológico, histoquímico e ultra-estrutural de fígados e linfonodos de bovinos com presença de macrófagos espumosos ("foam cells"). Pesq. Vet. Bras. 18:29-34.

Driemeier D., Döbereiner J., Peixoto P.V. \& Brito M.F. 1999. Relação entre macrófagos espumosos ("foam cells") no fígado de bovinos e ingestão de Brachiaria spp. no Brasil. Pesq. Vet. Bras. 19:79-83.

Driemeier D., Colodel E.M., Seitz A.L., Barros S.S. \& Cruz C.E.F. 2002. Study of experimentally induced lesions in sheep by grazing Brachiaria decumbens. Toxicon 40:1027-1031.

Drudi A., Guimarães D.M. \& Melo W.R. 1995. Recuperação de pastagens degradadas de Brachiaria decumbens nos cerrados do sudoeste goiano-I Diagnóstico de deficiências nutricionais. Comunicado Técnico. Empresa Goiana de Pesquisa Agropecuária, Goiânia, GO. 9p.

Embrapa 2005. Brazilian Enterprise for Agricultural Reserarch. In <www.cnpgc.embrapa.br/eventos/2005/workshop-mortebrachiaria> Accessed on December 26, 2009.

Fagliari J.J., Passipieri M. \& Oliveira J.A. 1983. Sintomas de fotossensibilidade em bezerros alimentados com leite materno. Arq. Bras. Med.Vet. Zootec. 35(4):479-484.

Fagliari J.J., Okuda H.T., Kuchembuck M.R.G. \& Curi P.R. 1993a. Intoxicação natural de bovinos pela micotoxina esporidesmina. I. Aspectos epidemiológicos. Arq. Bras. Med. Vet. Zootec. 45(3):263274.

Fagliari J.J., Oliveira J.A., Kuchembuck M.R.G. \& Curi P.R. 1993b. 
Intoxicação natural de bovinos pela micotoxina esporodesmina. II. Aspectos clínicos. Arq. Bras. Med. Vet. Zootec. 45(3):275-282.

Fagliari J.J., Oliveira J.A., Kuchembuck M.R.G. \& Curi P.R. 1993c. Intoxicação natural de bovinos pela micotoxina esporodesmina. III. Desenvolvimento ponderal de bovinos intoxicados. Arq. Bras. Med. Vet. Zootec. 45(3):283-289.

Fagliari J.J., Okuda H.T., Kuchembuck M.R.G. \& Curi P.R. 1994. Estudo de alguns constituintes sanguíneos de bovinos intoxicados naturalmente pela micotoxina espirodesmina. Arq. Bras. Med. Vet. Zootec. 46(5):457-475.

Fioravanti M.C. 1999. Incidência, avaliação clínica, laboratorial e anatomopatológica da intoxicação subclínica por esporidesmina em bovinos. PhD thesis, Faculdade de Medicina Veterinária e Zootecnia, University of the State of São Paulo (Unesp), Botucatu, SP. 256p.

Gomar M.S., Driemeier D., Colodel E.M. \& Gimeno E.J. 2005. Lectin histochemistry of foam cells in tissues of catle grazing Brachiaria spp. J. Vet. Med. Physiol. Pathol. Clin. Med. 52:18-21.

Górniak S.L. 2008. Plantas Tóxicas de Interesse Agropecuário, p.415458. In: Spinosa H.S., Górniak S.L., Palermo-Neto J. (Eds), Toxicologia Aplicada à Medicina Veterinária. Manole, São Paulo.

Graydon R.I., Hamid H. \& Zahari P. 1991. Photosensitization and crystal associated cholangiohepatopathy in sheep grazing Brachiaria decumbens. Aust. Vet. J. 68:234-236.

Láu H.D. 1990. Efeitos tóxicos de Lantana camara e de Pithomyces chartarum em búfalas. Doc.54, Embrapa-CPATU, Belém, PA. 18p.

Láu H.D \& Singh N.P. 1985. Eczema facial em ovinos infectados pelo Pithomyces chartarum em pastagem de quicuio-da Amazônia. Pesq. Agropec. Bras. 20(8):873-875.

Lee S.T., Mitchell R.B., Gardner D.R., Tokarnia C.H. \& Riet-Correa F. 2009. Measurement of steroidal saponins in Panicum and Brachiaria grasses in USA and Brazil. $8^{\text {th }}$ International Symposium on Poisonous Plants, João Pessoa, Paraíba, Brazil, p.121. (Abstract)

Lemos R.A.A. \& Leal C.R.B. 2008. Doenças de impacto econômico em bovinos de corte: perguntas e respostas. Editora UFMS, Campo Grande/MS, p.232-236.

Lemos R.A.A., Osório A.L.A.R., Rangel J.M.R. \& Herrero J.R.G.O. 1996a. Fotossensibilização e colangiopatia associada a cristais em bezerros ingerindo Brachiaria brizantha. Arq. Inst. Biológico, São Paulo, 63:22.

Lemos R.A.A., Ferreira L.C.L., Silva S.M., Nakazato L. \& Salvador S.C. 1996b. Fotossensibilização e colangiopatia associada a cristais em ovinos em pastagem com Brachiaria decumbens. Ciência Rural 26:109-113.

Lemos R.A.A, Salvador S.C. \& Nakazato L. 1997. Photosensitization and crystal associated cholangiohepatopathy in cattle grazing Brachiaria decumbens in Brazil. Vet. Human Toxicol. 39:376-377.

Lemos R.A.A., Nakazato L., Herrero J.R.G.O., Silveira A.C. \& Porfírio L.C. 1998. Fotossensibilização e colangiopatia associada a cristais em caprinos mantidos sob pastagens de Brachiaria decumbens no Mato Grosso do Sul. Ciência Rural 28:507-510.

Lemos R.A.A., Nogueira A.P.A., Souza R.I.C., Santos B.S., Carvalho N.M., Aniz A.C.M. \& Freitas P.C. 2009. Brachiaria spp poisoning in ruminants in Mato Grosso do Sul, Brazil. 8 International Symposium on Poinsonous Plants, João Pessoa, Paraíba, Brazil, p.98. (Abstract)

Macedo M.C.M. 2005. Pastagens no Ecossistema Cerrados: evolução das pesquisas para o desenvolvimento sustentável. Proc. $42^{a}$ Reunião Anual da Sociedade Brasileira de Zootecnia, Goiânia, GO, p.56-84.

Meagher L.P., Wilkins A.L., Miles C.O., Collin R.G. \& Fagliari J.J. 1996. Hepatogenous photosensitization of ruminants by Brachiaria decumbens and Panicum dichotomiflorum in the absence of sporidesmin: Lithogenic saponis may be responsible. Vet. Hum. Toxicol. 38:271274.
Mendonça F.S., Camargo L.M., Freitas S.H., Dória R.G.S., BaratellaEvêncio L. \& Evêncio-Neto J. 2008. Aspectos clínicos e patológicos de um surto de fotossensibilização hepatógena em ovinos pela ingestão de Brachiaria decumbens (Graminae) no município de Cuiabá, Mato Grosso. Ciênc. Anim. Bras. 9(4):1034-1041.

Moreira C.N., Banys V.L., Pinto A.S., Franco L.A.S., Haraguchi M. \& Fioravanti M.C.S. 2009a. Bovinos alimentados com capim Brachiaria e Andropogon: Desempenho, avaliação da quantidade de esporos do fungo Pithomyces chartarum e teor de saponinas nas pastagens. Ciênc. Anim. Bras. 10(1):184-194.

Moreira C.N., Moraes M., Garcia E.C., Neto S.C., Araújo E.G. \& Fioravanti M.C.S. 2009b. Bovinos alimentados com Brachiaria spp e Andropogon gayanus: alterações histológicas dos fígados e linfonodos. Ciênc. Anim. Bras. 10(1):206-218.

Mustafa V.S. 2009. Intoxicação por Brachiaria spp em ovinos no Brasil Central. MSc thesis, University of Brasília, Brasília, DF. 71p.

Nazário W., Amaral R.E.M., Angeli V.M., Capellaro C.E.M.P.D.M., Fernandes N.S. \& Camargo W.V.A. 1977. Intoxicação experimental produzida pelo Pithomyces chartarum (Berk. et Curt.) M.B. Ellis, isolado de Brachiaria decumbens. Biológico, São Paulo, 43(5/6):125-131.

Nazário W., Mandorino I., Maravolta V.A., Dupas W. \& Weyand S.C. 1985. Fotossensibilização em ovinos mantidos em pastagem de Brachiaria ruziziensis Germain et Evrard, no Estado de São Paulo, com provável participação do fungo Pithomyces chartarum. Revta Brasil. Med. Vet. 7(7):216-218.

Nobre D. \& Andrade S.O. 1976. Relação entre fotossensibilização em bovinos jovens e gramímea Brachiaria decumbens Stapf. Biológico, São Paulo, 42(11/12):249-258.

Opasina B.A. 1985. Photosensitization jaundice syndrome in West African dwarf sheep and goats grazed on Brachiaria decumbens. Trop. Grasslands 19(3):120-123.

Purchio A., Correa B., Galhardo M. \& Pelicci P. 1988. Ocorrência de surto de eczema facial em ovinos, na região de São Manuel, Estado de São Paulo. Rev. Fac. Med. Vet. Zoot. Univ. São Paulo 25(1):135-137.

Riet-Correa F. \& Medeiros R.M. 2000. Intoxicações por plantas no Brasil e no Uruguai: importância econômica, controle e riscos para a Saúde Pública. Pesq. Vet. Bras. 21(1):38-42.

Riet-Correa F. \& Méndez M.C. 2007. Intoxicações por plantas e micotoxinas, p.99-219. In: Riet-Correa F., Schild A.L., Lemos R.A.A. \& Borges J.R.J. (Eds), Doenças de Ruminantes e Eqüídeos. Vol.2. Editora Pallotti, Santa Maria, RS.

Riet-Correa G., Riet-Correa F., Schild A.L. \& Driemeier D. 2002. Wasting and death in cattle associated with chronic grazing of Brachiaria decumbens. Vet. Hum. Toxicol. 44(3):179-180.

Riet-Correa B., Riet-Correa F., Oliveira Jr C.A. \& Riet-Correa G. 2010. Alterações histológicas em figados e linfonodos mesentéricos de bubalinos em pastagem de Brachiaria spp. no sudeste e nordeste do Pará e em campo nativo da llha do Marajó. Pesq. Vet. Bras. 30(10): 705-711.

Rozza D.B., Seitz A.L., Bandarra P.M., Santos E.O. \& Driemeier D. 2004. Fotossensibilização por Brachiaria decumbens em búfalo. Pesq. Vet. Bras. 24(Supl.):55-56.

Russomanno O.M.R., Portugal M.A.S.C., Coutinho L.N., Calil E.M.B. \& Figueiredo M.B. 2003. Leptosphaerulina chartarum (= Pithomyces chartarum) e seu envolvimento no eczema facial: artigo de revisão. Arqs Inst. Biológico, São Paulo, 70(3):385-390.

Santos Jr H.L. 2008. Estudo da toxicidade de diferentes estágios de crescimento de Brachiaria decumbens em ovinos. MSc thesis, University of Brasília, Brasília, DF. 70p.

Salam-Abdullah A., Lajis N.H., Bremner J.B., Davies N.W., Mustapha W. \& Rajion M.A. 1992. Hepatotoxic constituents in the rúmen of Brachiaria decumbens intoxicated sheep. Vet. Human Toxicol. 34(2):154-155.

Saturnino K.C., Marian T.N., Barbosa-Ferreira M., Brum K., Fernandes 
C.E.S. \& Lemos R.A.A. 2010. Intoxicação experimental por Brachiaria decumbens em ovinos confinados. Pesq. Vet. Bras. 30(3):195-202.

Seiffert N.F. 1980. Gramíneas forrageiras do gênero Brachiaria. Bolm Téc.1, Embrapa-CNPGC, Campo Grande, MS. 83p.

Serrão E.A.D. 1977. Adaptação de gramíneas do gênero Brachiaria na Amazônia; In: Empresa Goiana de Pesquisa Agropecuaria (Ed.), Encontro sobre Forrageiras do Gênero Brachiaria, Emgopa/Emater, Goiania, GO. 31p.

Schenk M.A.M. \& Schenk J.A.P. 1983. Fotossensibilização em bovinos: aspectos gerais. Comun. Téc.19, Embrapa Gado de Corte, Campo Grande, MS. 4p.

Schenk M.A.M., Nunes S.G. \& Silva J.M. 1991. Ocorrência de fotossensibilização em eqüinos mantidos em pastagem de Brachiaria humidicola. Comum. Téc., Embrapa Gado de Corte, Campo Grande, MS. 3p.

Silveira J.A.S., Albernaz T.T., Silva e Silva N., Lopes C.T.A., Cerqueira V.D., Oliveira C.M.C.H., Duarte M.D. \& Barbosa J.D. 2009. Fotossensibilização hepatógena em caprinos associada à ingestão de
Brachiaria brizantha no estado do Pará. Ciênc. Anim. Bras. 1(Supl.): 336-441.

Soares P.C., Mota R.A., Teixeira M.N. \& Santos N.V.M. 2000. Aspectos epidemiológicos e clínicos da intoxicação por Pithomyces chartarum em ovinos da raça Santa Inês, no município de Gravatá- PE. Revta Bras. Ciênc. Vet. 7(2):78-82.

Souza R.I.C., Riet-Correa F., Barbosa-Ferreira M., Brum K.B., Fernandes C.E. \& Lemos R.A.A. 2010. Intoxicação por Brachiaria spp. em bovinos no Mato Grosso do Sul. Pesq. Vet. Bras. 30(12):1036-1042.

Temperini J.A. \& Barros M.A. 1977. Revisão sobre aspectos químicos e físicos ligados ao fenômeno de fotossensibilização e efeitos biológicos da espirodesmina obtida do fungo Pithomyces chartarum (Berk. et Curt.) M.B. Ellis. Biológico, São Paulo, 43(5/6):103-110.

Tokarnia C.H. \& Langenegger J. 1983. Relatório de visita a fazenda Vargem Bonita, município de Grajaú, Maranhão. Relatório do Instituto de Biologia Animal, Seropédica, RJ. $5 p$.

Tokarnia C.H., Döbereiner J.A. \& Peixoto P.V. 2000. Plantas Tóxicas do Brasil. Editora Helianthus, Rio de Janeiro, RJ, p.164-175. 